\title{
Analysis of Back Surface Field (BSF) Performance in P-Type And N-Type Monocrystalline Silicon Wafer
}

\author{
Ferdiansjah $^{1, *}$, Faridah $^{1}$, and Kelvian Tirtakusuma Mularso ${ }^{l}$ \\ ${ }^{1}$ Department of Nuclear Engineering and Engineering Physics, Universitas Gadjah Mada, Indonesia.
}

\begin{abstract}
Back Surface Field (BSF) has been used as one of means to enhance solar cell performance by reducing surface recombination velocity (SRV). One of methods to produce BSF is by introducing highly doped layer on rear surface of the wafer. Depending on the type of the dopant in wafer, the BSF layer could be either $\mathrm{p}+$ or $\mathrm{n}+$. This research aims to compare the performance of BSF layer both in p-type and n-type wafer in order to understand the effect of BSF on both wafer types.

Monocrystalline silicon wafer with thickness of $300 \mu \mathrm{m}$, area of $1 \mathrm{~cm}^{2}$, bulk doping level NB $=1.5 \times 10^{16} / \mathrm{cm}^{3}$ both for $\mathrm{p}$-type wafer and n-type wafer are used. Both wafer then converted into solar cell by adding emitter layer with concentration $\mathrm{NE}=7.5 \times 10^{18} / \mathrm{cm}^{3}$ both for $\mathrm{p}$-type wafer and $\mathrm{n}$-type wafer. Doping profile that is used for emitter layer is following complementary error function (erfc) distribution profile. BSF concentration is varied from $1 \times 10^{17} / \mathrm{cm}^{3}$ to $1 \times 10^{20} / \mathrm{cm}^{3}$ for each of the cell. Solar cell performance is tested under standard condition, with $\mathrm{AM}_{1.5 \mathrm{G}}$ spectrum at $1000 \mathrm{~W} / \mathrm{m}^{2}$. Its output is measured based on its open circuit voltage $\left(V_{O C}\right)$, short circuit current density $\left(J_{S C}\right)$, efficiency $(\eta)$, and fill factor $(F F)$.

The result shows that the value of $V_{O C}$ is relatively constant along the range of BSF concentration, which is $0.694 \mathrm{~V}-0.702 \mathrm{~V}$. The same pattern is also observed in $F F$ value which is between $0.828-0.831$. On the other hand, value of $J_{S C}$ and efficiency will drop against the increase of BSF concentration. Highest $J_{S C}$ which is $0.033 \mathrm{~A} / \mathrm{cm}^{2}$ and highest efficiency which is $18.6 \%$ is achieved when BSF concentration is slightly higher than bulk doping level. The best efficiency can be produced when BSF concentration is around $1 \times 10^{17} \mathrm{~cm}^{-3}$.. This result confirms that surface recombination velocity has been reduced due to the increase in cell's short circuit current density and its efficiency.

In general both p-type and n-type wafer will produce higher efficiency when BSF is applied. However, the increase is larger in p-type wafer than in n-type wafer. Better performance for solar cell is achieved when BSF concentration is slightly higher that bulk doping level because at very high BSF concentration the cell's efficiency will be decreased.
\end{abstract}

\section{Introduction}

Solar cell has grown thinner in past decade due to the desire to reduce material cost. A lot of research has been performed in order to find ways of reducing cell's thickness without sacrificing its efficiency. Current solar cell that widely produced has P-type based monocrystalline wafer and it shows an increase in its effciency. However when the wafer become thinner, effect such as surface recombination will become dominant, hence a way to limit or reduce this effect should be applied. One the method to limit backsurface recombination in a P-type wafer is by applying aluminium layer upon the rear surface of the cell. This layer will function as internal electric field generator that will repel photogenerated minority carrier near the rear surface, and therefore will reduce back surface recombination velocity. The effectiveness of aluminium layer as back surface field generator will depend on Al concentration. However this concentration will be limited to its maximum solid solubility in $\mathrm{Si}$, which is around $1018 \mathrm{~cm}-3$ at the standard firing temperature of around $750 \mathrm{oC}[1]$.

On the other hand, N-type silicon wafer exhibits several advantages compared to the P-type wafer. Some of the advantages of $\mathrm{N}$-type solar cells are : no formation of boron-oxygen complexes that will produce degradation in wafer, high tolerance for common impurities, having longer diffusion length at similar doping level with the other dopantts, lower doping level is needed to produce same value of conductivity on the $\mathrm{nn}+$ junction formation [2].

\section{Theory}

Minority carrier recombination is one of mechanism that reduce quantum efficiency as well as power efficiency [3]. Back Surface Field formation on the rear surface of the cell in the form of $\mathrm{p}^{+}$layer upon P-type wafer has shown the ability to increase cell's efficency $2.5 \%$ from its original value when $\mathrm{p}^{+}$layer thickness is around $20 \mu \mathrm{m}$ and doping concentration is $10^{19} \mathrm{~cm}^{-3}$ [4].

Another type of BSF is using $\mathrm{n}^{+}$layer upon $\mathrm{N}$-type wafer. When $\mathrm{n}^{+}$layer thickness is around $2 \mu \mathrm{m}$ and its peak doping level is around $4.16 \times 10^{19} \mathrm{~cm}^{-3}$ th $\mathrm{e}$ maximum efficiency that can be reached is around $19.98 \%$ [5].

BSF formation on dendritic web silicon wafer also produced an increase on efficiency. Effciency as high as $17.3 \%$ could be achieved when BSF with $n+$ type layer

*Corresponding author: ferdiansjah@ugm.ac.id 
with peak doping level of $3 \times 10^{20} \mathrm{~cm}^{-3}$ and thickness of $0.7 \mu \mathrm{m}$ is applied on the solar cell [6].

Solar cell with PERT and PERL structure also get benefit when BSF is applied. When peak doping level in $\mathrm{n}+$ layer is $5 \times 10^{18} \mathrm{~cm}^{-3}$ and its thickess is $1.5 \mu \mathrm{m}$, the efficiency could reach $22.7 \%$ [7].

In a solar cell when minority carrier generation dominated the process, then the open circuit voltage, $V_{O C}$ could be given as

$$
V_{O C}=\frac{k T}{q} \ln \left[\left(\frac{I_{S C}}{I_{0}}\right)+1\right]
$$

From Eq. 1, it can be seen that $V_{O C}$ is limited by dark saturation current $I_{0}$, that is produced within base layer $\left(I_{0 b}\right)$ and within emitter layer $\left(I_{0 e}\right)$. For saturation base current $I_{o b}$, its value will depend on bulk recombination and also BSF saturation current. The value of these variables could be gotten from measurement of bulk life time and Back Surface Recombination Velocity (BSRV). The $I_{o b}$ then could be calculated according the equation

$$
I_{o b}=I_{o b L}\left(\frac{I_{o r}+I_{o b L} \tanh \left(\frac{W_{B}}{L_{B}}\right)}{I_{o b L}+I_{o r} \tanh \left(\frac{W_{B}}{L_{B}}\right)}\right)
$$

where $I_{o b L}$ is ideal base saturation current, $L_{B}$ is minority carrier diffusion length and base, $W_{B}$ is base width and Ior is saturated current at rear surface [8].

On the other hand the BSRV at BSF layer when structure such as n-p- $\mathrm{p}^{+}$is used could be estimated by

$$
B S R V=\frac{N_{A}}{N_{A}^{+}} \exp \left(\frac{\Delta V_{G}^{+}}{k T / q}\right) \cdot\left(\frac{S_{0}+\frac{D_{e}^{+}}{L_{e}^{+}} \tanh \left(\frac{W^{+}}{L_{e}^{+}}\right)}{1+\frac{S_{0} L_{e}^{+}}{D_{e}^{+}} \tanh \left(\frac{W^{+}}{L_{e}^{+}}\right)}\right)
$$

where $N_{A}$ and $N_{A}^{+}$is dopant concentration in wafer and BSF layer, respectively, $\Delta V_{G}{ }^{+}$is bandgap narrowing due to heavy dopantt concentration in BSF layer, $S_{0}$ is surface recombination velocity without BSF layer, $D_{e}{ }^{+} / L_{e}^{+}$is the electron (minority carrier) diffusivity to diffusion length ratio in BSF layer, and $W^{+}$is BSF thickness [1].

\section{Methodology}

Solar cell that was under consideration has properties as show in the Table 1. Solar cell performance is simulated under Standard Testing Condition i.e. in ambient temperature of $25^{\circ} \mathrm{C}$ and $\mathrm{AM} 1.5 \mathrm{G}$ spectrum with intensity of $1000 \mathrm{~W} / \mathrm{m}^{2}$.

Simulation was performed to extract variable such as open circuit voltage $\left(V_{o c}\right)$, short circuit current density $\left(J_{s c}\right)$, efficiency $(\eta)$, and fill factor $(F F)$ as a measure solar cell performance. All of these variables are examines both for P-type wafer and $\mathrm{N}$-type wafer in order to find the effect of different type of wafer against their performance. All data were generated using PC1D

\begin{tabular}{|c|c|c|}
\hline Parameter & Value & Unit \\
\hline Surface area & 1 & $\mathrm{~cm}^{2}$ \\
\hline Junction depth & 1.56 & $\mu \mathrm{m}$ \\
\hline $\begin{array}{l}\text { Peak doping level emiter } \\
\text { (erfc) }\end{array}$ & $7.5 \times 10^{18}$ & $\mathrm{~cm}^{-3}$ \\
\hline Emitter series resistivity & 0.3 & $\Omega$ \\
\hline Base series resistivity & 0.1 & $\Omega$ \\
\hline Cell's thickness & 300 & $\mu \mathrm{m}$ \\
\hline $\begin{array}{l}\text { Background doping (both for } \\
\mathrm{p} \text { and n-type wafer) }\end{array}$ & $1.5 \times 10^{16}$ & $\mathrm{~cm}^{-3}$ \\
\hline Bulk minority lifetime & 51 & $\mu \mathrm{m}$ \\
\hline $\begin{array}{l}\text { Surface recombination for } \\
\text { front area }\end{array}$ & 100 & $\mathrm{~cm} \cdot \mathrm{s}^{-1}$ \\
\hline $\begin{array}{c}\text { Surface recombination for rear } \\
\text { area }\end{array}$ & $10^{5}$ & $\mathrm{~cm} \cdot \mathrm{s}^{-1}$ \\
\hline
\end{tabular}
v.5.9.
Table 1. Solar Cell properties.

\section{Result and Discussion}

\subsection{Effect of peak doping level of BSF ( $\left.N_{B S F}\right)$ on open circuit voltage $\left(V_{o c}\right)$}

When peak doping level of BSF layer is increased, it will increase $V_{o c}$ value. This happened when doping level on BSF layer is increase up to $2.11 \times 10^{19} \mathrm{~cm}^{3}$ both for $\mathrm{p}^{+}$ and $\mathrm{n}^{+}$as BSF layers. After the concnetration on BSF layer higher than $2.64 \times 10^{19} \mathrm{~cm}^{3}$, it show small decrease on $V_{o c}$. This result could be shown on the Fig. 1 .

Another solar cell with wafer thickness of $300 \mathrm{~mm}$ that has bulk lifetime of $200 \mu \mathrm{s}$ and wafer resistivity of 1.3 $\Omega$-cm show the same result. It produces $V_{o c}$ above 660 $\mathrm{mV}$, short circuit current density of $37 \mathrm{~mA} / \mathrm{cm}^{2}$, and $I_{o s}$ and $I_{o x}$ of $8 \times 10^{14} \mathrm{~cm}^{3}$ and $3 \times 10^{-13} \mathrm{~cm}^{3}$, respectively [9]. The majority factor is due to bulk minority carrier lifetime. The higher bulk minority carrier lifetime, the higher the $V_{o c}$ will be. Higher minority carrier lifetime could be achieved when BSF layer is applied to reduce Back Surface Recombination Velocity (BSRV). However, at certain point, the $V_{o c}$ will saturate at a high value. In this case, the saturation value for $V_{o c}$ is around $698 \mathrm{mV}$ for P-type wafer and $702 \mathrm{mV}$ for $\mathrm{N}$-type wafer and these condition were reached at BSF doping level of $2.64 \times 10^{\text {19 }}$ $\mathrm{cm}^{3}$. 


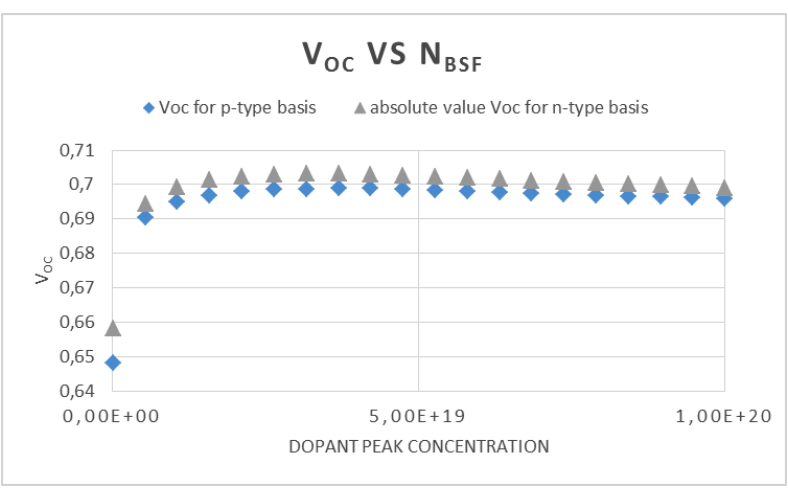

Fig 1. Effect of peak doping level on BSF layer $\left(N_{B S F}\right)$ to open circuit voltage $\left(V_{O C}\right)$

\subsection{Effect of peak doping level of BSF ( $N_{B S F}$ ) on short circuit current $\left(I_{S C}\right)$}

It has already been confirmed by many researches that BSF layer will increase short circuit current within solar cells. This effect due to the generation of electric field on the rear surface of the cell. The electric field will help minority carriers that have been generated near the rear surface to escape from recombination process because the electric field will swap the monority carries away from the rear surface of the cell. This mecahnism will enhance carriers collection probability that is produced from long range wavelength because this type of wavelength will tends to be absorbed at the rear side of the cell.

However, BSF usage has limitation when it produces opposite effect. Figure 2 shows that when BSF doping concentration increase there is a tendency that the short circuit current will also decrease.

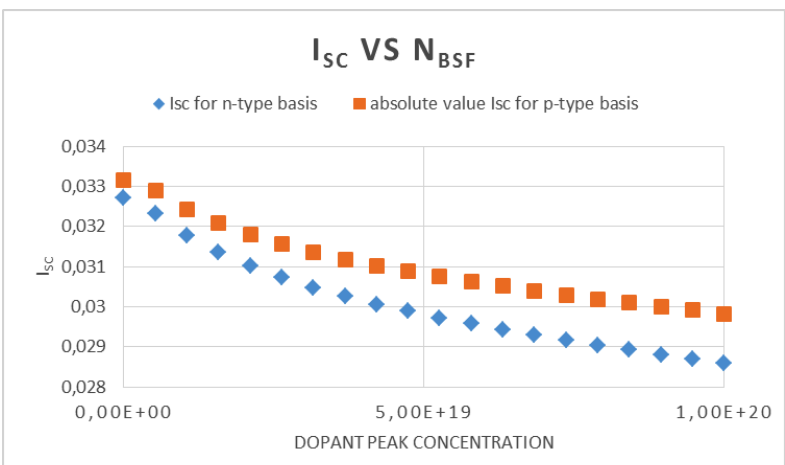

Fig 2. Effect of peak doping level on BSF layer $\left(N_{B S F}\right)$ to short circuit current $\left(I_{S C}\right)$

Highest short circuit current is achieved when BSF layer has value of $1 \times 10^{n} \mathrm{~cm}^{3}$. Once this value is increased, the $I_{s c}$ will begin to reduce. Reduction of ISC when dopant concentration on BSF layer increases is attributed to Auger recombination that begin to dominate on higher doping level. From Figure 2 it could be seen that the value of $I_{s c}$ for P-type wafer is higher than $\mathrm{N}-$ type wafer. This situation happened because electron as minority carrier in P-type wafer has higher mobility than hole as minority carrier in N-type wafer. The higher carrier mobility will increase the collection probability within the cell, and as the result, it will increase short current.

\subsection{Effect of peak doping level of BSF $\left(N_{B S F}\right)$ on Efficiency}

Efficiency of solar cell measures the effectiveness of the cell to convert photon energy into electricity. The maximum electric power that is generated within the cell will be proportional to its efficiency. This electric power will be greatly affected by its current insofar as the voltage does not change during the operation. This situation is applied when Fig. 1 is considered.

Figure 1 shows that $V_{o c}$ does not change much when BSF doping concentration increased. However, the $I_{s c}$ decreased when BSF doping concentration increased as shown in Fig. 2. This situation will produce efficiency curve against BSF doping concentration that is given in Fig. 3. In Figure 3, it can be seen that efficiency will decrease when BSF doping concentration increase. The pattern on the curve is similar with curve in Fig. 2 so it can be concluded that in this situation short circuit current will dominate the efficiency. Besteffciency for both tipe of solar cell were produced at BSF doping level of $1 \times 10^{17} \mathrm{~cm}^{-3}$. At this level, BSF concentration will high enough to produce electric field while keeping the Auger recombinaation as lower as possible. Increasing the BSF concentration above this level will reduce efficiency because Auger recombination on the back surface will begin to dominate the process.

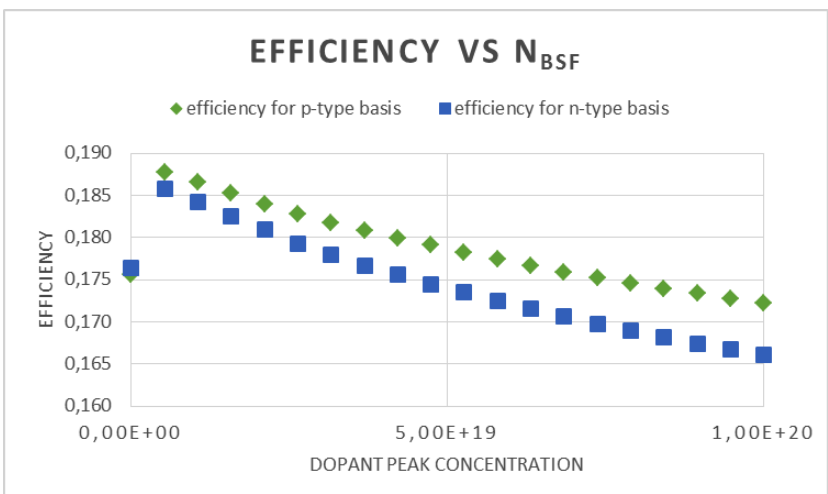

Fig 3. Effect of peak doping level on BSF layer $\left(N_{B S F}\right)$ to Efficiency

\subsection{Effect of peak doping level of BSF $\left(N_{B S F}\right)$ on Fill Factor (FF)}

Some researches $[9,10]$ show that Fill Factor $(F F)$ will be affected by shunt resistance, series resistance, and ideality factor of the diode. All of these factor could be extracted into single factor, that is $V_{o c}$. Therefore $V_{o c}$ will directly affect FF. Green-Swanson approximation as given in Equation 4 predicts the dependency of $F F$ on $V_{o c}$ [9]. 


$$
F F=\frac{v_{O C^{-}} \ln \left(v_{O C}+0.72\right)}{v_{O C^{+1}}}
$$

where $v_{o c}$ is defined as:

$$
v_{O C}=\frac{V_{O C}}{\left({ }^{n k T} / q\right)}
$$

$n$ being the ideality factor for diode. Figure 4 show how $F F$ behaves when BSF doping level changes.

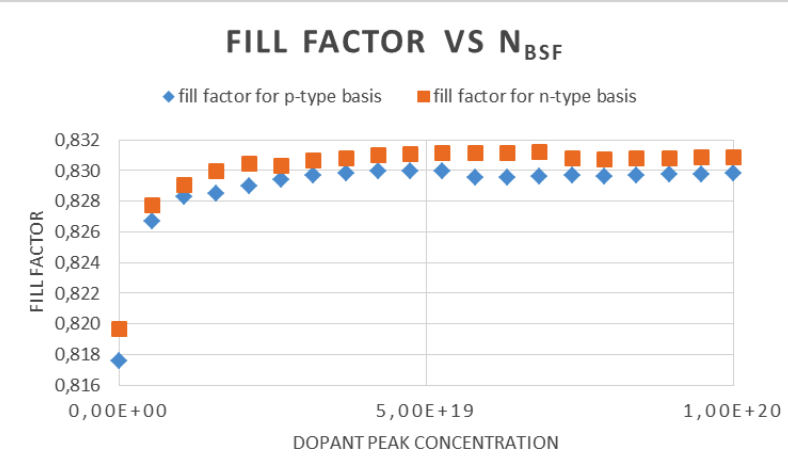

Fig 4. Effect of peak doping level on BSF layer $\left(N_{B S F}\right)$ to Fill Factor $(F F)$

In Figure 4 it can be seen that $F F$ does not change significantly when $V_{o c}$ does not change. Figure 1 and Figure 4 together show consistency and in agreement to each other.

\section{Conclusions}

In general both p-type and n-type wafer will produce higher efficiency when BSF is applied. However, the increase is larger in p-type wafer than in n-type wafer. Better performance for solar cell is achieved when BSF concentration is slightly higher that bulk doping level because at very high BSF concentration the cell's efficiency will be decreased. Best result is achieved when BSF layer doping concentration has value of $1 \times 10^{17} \mathrm{~cm}^{-3}$.

\section{References}

1. G. Xin, Y. Xuegong, Y. Deren, Efficiency improvement of crystalline silicon solar cells with a backsurface field produced by boron and aluminum co-doping, Scripta Materialia, 66 (2012) pp. 394397

2. J. Ulrich, S. Dominik, B. Jan, J. Stefan, P. Ralf, A laser based process for the formation of a local back surface field for n-type silicon solar cells, Thin Solid Films, 519 (2011) pp. 3827-3830

3. S. C. Kwang, Parametric Simulation of The Back Surface Field Effect In The Silicon Solar Cell, Solid State Science Journal, 29 (2014) pp. 48-51
4. A. B. Prakoso, Ferdiansjah, Faridah, Optimasi Pembentukan Lapisan Boron P+ Pada Permukaan Belakang Sel Surya Untuk Peningkatan Efisiensi Sel Surya Berbasis Wafer Silikon Monokristal, Teknofisika, Jurnal Ilmiah Bidang Teknik Fisika, 1 (2012) pp. 20-26

5. P. Procel, V. Maccaronio, F. Crupi, G. Cocorullo, M. Zanuccoli, Analysis of The Impact of Rear Side Geometry on Performance of Back-Contact BackJunction Solar Cells, Fotonica AEIT Italian Conference, (2014) pp.1-4

6. S. Narasimha, G. Crotty, T. Krygowski, A. Rohatgi, D. L. Meier, Back Surface Field And Emitter Passivation Effects Ni The Record High Efficiency N-Type Dendritic High Efficiency NType Dendritic Web Silicon Solar Cells, Photovoltaic Specialists Conference, (1997), pp. $235-238$

7. B. Jan, S. Bernd, M. Ralph, B. Jonas, K. Mathias, M. Andrew, R. Armin, H. Martin, G. Stefan, High Efficiency N-Type PERT and PERL Solar Cells, IEEE Photovoltaics Specialists Conference (PVSC), (2014) pp. 3637 - 3640

8. P. Sungeun, P. Hyomin, K. Yoonmook, L. HaeSeok, K. Donghwan, Analysis of aluminum back surface field at different wafer specifications in crystalline silicon solar cells, Current Applied Physics 16 (2016) pp. 1062-1068

9. A. G. Martin, Solar Cell Fill Factors: General Graph and Empirical Expression, Solid-State Electronics, 24, 8 (1981) pp. 788-789

10. M. Richard, Swanson, R. Sinton, Advances in Solar Energy, American Solar Energy Society Vol. 1, New York (1983) 